\title{
Serum Levels of Anti-Citrullinated Protein Antibody (ACPA) and TWEAK in Patients with Rheumatoid Arthritis: Association with Disease Activity and Treatment Modalities
}

\author{
Romatoid Artritli Hastalarda Serum TWEAK ve Anti-Sitrülinlenmiş Protein Antikor \\ (ACPA) Seviyeleri: Tedavi Yöntemleri ve Hastalık Aktivitesiyle İlişkisi
}

\author{
Murat KARKUCAK, ${ }^{1}$ Erhan ÇAPKIN, ${ }^{1}$ Haşim ÇAKIRBAY, ${ }^{1}$ Ayşe AKYÜZ, ${ }^{2}$ Ahmet ALVER, ${ }^{2}$ \\ Ayşegül CANSU, ${ }^{3}$ Duygu DEMİROK, ${ }^{1}$ Mehmet TOSUN ${ }^{1}$ \\ ${ }^{1}$ Department of Physical Medicine and Rehabilitation, Medical Faculty of Karadeniz Technical University, Trabzon, Turkey; \\ ${ }^{2}$ Department of Biochemistry, Medical Faculty of Karadeniz Technical University, Trabzon, Turkey; \\ ${ }^{3}$ Department of Radiology, Medical Faculty of Karadeniz Technical University, Trabzon, Turkey
}

\begin{abstract}
Objectives: In this study, we evaluated the serum levels of a serum TNF-related weak inducer of apoptosis (TWEAK) and anti-citrullinated protein antibody (ACPA) and investigated the possible correlation of these parameters with disease activity, cytokine levels and anti-TNF-alpha treatment in patients with rheumatoid arthritis (RA).
\end{abstract}

Patients and methods: Fifty-one patients with RA (39 females and 12 males) and 25 healthy controls were enrolled in the study. Of these, 22 patients were on anti-TNF-alpha and 29 were solely on disease-modifying anti-rheumatic drugs. Serum TWEAK, anti-ACPA [anti-modified citrullinated vimentin (MCV) and anticyclic citrullinated peptide, (CCP)], TNF-alpha, and interleukin-1 levels were determined by enzyme-linked immunosorbent assay (ELISA). The disease activity of RA was assessed according to Disease Activity Score 28 (DAS28). Radiographs were scored according to the modified Sharp methods.

Results: The RA patients had significantly higher anti-MCV and anti-CCP levels. When RA patients and controls were evaluated for serum TWEAK levels, there was no statistically significant difference $(p=0.765)$. No significant correlation was detected between the anti-CCP, anti-MCV, and modified Sharp scores. A significant positive correlation was determined among anti-MCV, anti-CCP, and modified Sharp scores. There was a negative correlation between anti-CCP levels and serum TWEAK levels in RA patients $(r=-0.84, p=0.471)$ that was not statistically significant.

Conclusion: Our study has shown that levels of anti-MCV and anti-CCP are higher in RA patients than in controls, and these also correlates with the modified Sharp scores. TWEAK levels were similar for RA patients receiving different medications and the controls.

Key words: Anti-citrullinated protein antibody; anti-TNF-alpha; rheumatoid arthritis; TWEAK.

\begin{abstract}
Amaç: Bu çalışmada romatoid artritli (RA) hastalarda serum tümor nekroz faktörü (TNF) ile ilişkili zayıf apoptoz indükleyici (TWEAK) ve anti-sitrülinlenmiş protein antikorların (ACPA) düzeyi araştırıldı ve bu parametrelerin hastalık aktivitesi, sitokin seviyeleri ve anti-TNF-alfa tedavisi ile olası ilişkisi değerlendirildi.
\end{abstract}

Hastalar ve yöntemler: Çalışmaya 51 RA'lı hasta (39 kadın ve 12 erkek) ve 25 sağlıklı kontrol dahil edildi. Hastalardan 22'si anti-TNF-alfa ve 29 'u sadece hastalığı modifiye edici antiromatizmal ilaçlar almaktaydı. Serum TWEAK, anti-APCA [(antimodifiye strülinlenmiş vimentin (MCV) ve anti-siklik sitrülinlenmiş peptid, (CCP)], TNF-alfa ve interlökin-1 düzeyleri enzim bağlı immünosorbent testiyle (ELISA) ölçüldü. Romatoid artrite ilişkin hastalık aktivitesi Hastalık Aktivitesi Skoru 28'e (DAS28) göre değerlendirildi. Radyografiler modifiye Sharp yöntemlerine göre puanlandı.

Bulgular: Romatoid artritli hastalar anlamlı ölçüde daha yüksek anti-MCV ve anti-CCP düzeylerine sahipti. Romatoid artritli hastalar ve kontroller serum TWEAK düzeyleri yönünden değerlendirildiğinde istatistiksel olarak anlamlı herhangi bir fark yoktu $(p=0.765)$. Anti-CCP, anti-MCV ve modifiye Sharp skorları arasında anlamlı bir ilișki tespit edilmedi. Anti-CCP, anti-MCV ve modifiye Sharp skorları arasında anlamlı bir pozitif ilişki tespit edildi. Romatoid artritli hastalarda serum TWEAK düzeyleri ile anti-CCP düzeyleri arasında bir negatif ilişki $(r=-0.84, p=0.471)$ mevcuttu, ancak bu istatistiksel olarak anlamlı değildi.

Sonuç: Çalışmamız anti-CCP ve anti-MCV düzeylerinin RA'lı hastalarda kontrol grubundan daha yüksek olduğunu ve aynı zamanda modifiye Sharp skoru ile ilişkili olduğunu gösterdi. TWEAK düzeyleri farklı ilaç tedavileri alan RA'lı hastalar ile kontroller arasında benzerdi.

Anahtar sözcükler: Anti- sitrülinlenmiş protein antikor; anti-TNF-alfa; romatoid artrit; TWEAK.

Received: May 9, 2010 Accepted: October 14, 2010

Correspondence: Murat Karkucak, M.D. Karadeniz Teknik Üniversitesi Tıp Fakültesi Fiziksel Tıp ve Rehabilitasyon Anabilim Dalı, 61100 Trabzon, Turkey.

Tel: +90 462 - 3775613 e-mail: muratkarkucak@yahoo.com

(O2011 Turkish League Against Rheumatism. All rights reserved. 
Rheumatoid arthritis (RA) is an autoimmune disease characterized by inflammation of synovial tissue and destruction in the joints. Treatment and early diagnosis of RA are very important. Therefore, specific laboratory tests are desirable to help in identifying early RA. Autoantibodies to citrullinated proteins [anti-perinuclear factor, anti-keratin antibodies, anticyclic citrullinated peptide (anti-CCP), and anti-Sa (vimentin)] have been described in other studies. ${ }^{[1]}$ These antibodies may serve as a powerful serologic marker for early diagnosis and prognostic prediction of RA. ${ }^{[2,3]}$ While the specificity of these tests is above $90 \%$, sensitivity varies between $33 \%$ and $87.2 \% .^{[1]}$ Recently, studies have been reported that are associated with the poor radiographic prognosis of anti-mutated citrullinated vimentin (anti-MCV). ${ }^{[4,5]}$

The cytokine tumor necrosis factor (TNF)-related weak inducer of apoptosis (TWEAK) is a new member of the TNF family. It is known that TWEAK induces the production of cytokines that are involved in the pathogenesis of RA. ${ }^{[6]}$ Anti-TNF-alpha treatment has been associated with dramatic improvements in the clinical signs and symptoms of RA. ${ }^{[7]}$ However, some patients respond poorly to anti-TNF treatment. New TNF family members may explain this issue. In a recent study, it was reported that serum TWEAK levels in patients with RA were correlated with disease activity, and these significantly decreased with antiTNF-alpha treatment. ${ }^{[8]}$

In this study, we investigated the serum levels of TWEAK, anti-CCP, and anti-MCV in patients with RA and attempted to determine whether the aforementioned parameters are associated with disease activity, levels of cytokines (TNF and interleukin-1 (IL-1), and anti-TNF-alpha treatment.

\section{PATIENTS AND METHODS}

This study was conducted on patients with RA admitted to our polyclinic between June 2008 and October 2008. Fifty-one RA patients and 25 healthy volunteers were enrolled in this study. All patients were adults over the age of 16 and had a definite diagnosis of RA according to the American College of Rheumatology (ACR) 1987 revised criteria. ${ }^{[9]}$ The patients with RA $(\mathrm{n}=51)$ underwent physical examinations, and their clinical characteristics were recorded. Informed consent was obtained before the examination, and the local ethics committee of the university granted approval for the study. Controls $(n=25)$ were matched to the patients with RA by age and gender. Forty-two RA patients were receiving treatment with the single or combined disease-modifying antirheumatic drugs (DMARDs) methotrexate, sulfasalazine, and lenfluamid alone or taking them in combination with corticosteroids ( $\leq 10 \mathrm{mg} /$ day). Twenty-two patients with RA were on anti-TNF-alpha treatments (etanercept, adalimumab and infliximab). These patients responded to the antiTNF-alpha treatment [(improvement of $>0.6$ in Disease Activity Score 28 (DAS28 score)]. Thirteen out of the patients on anti TNF treatment were also receiving DMARDs.

At the time of the blood sample collection, the disease activity of patients with RA was assessed according to the 28-joint count DAS28 using the number of swollen and tender joints. Radiographic assessments of hands and feet were performed using the van der Heijde modified total Sharp scores (mTSS).$^{[10]}$ Radiographs were scored by two specialized radiologists who shared information about the study protocol. The mean score of two readers was used for analyses.

\section{Laboratory parameters}

Serum concentrations of TWEAK, anti-ACPA [(anti-modified citrullinated vimentin (MCV) and anti-cyclic citrullinated peptide, (CCP)], TNF-alpha, and IL-1 were detected by commercially available, enzyme-linked immunosorbent assays (ELISAs) using the manufacturer's instructions. AntiCCP was detected by a second generation. Values $>25 \mathrm{U} / \mathrm{ml}$ for anti-CCP were considered positive. These were consistent with the recommendation of the manufacturer (Euro-Diagnostica, Malmö, Sweden). ELISA kits for human TWEAK were purchased from Bender Medsystems, Vienna, Austria. The serum levels of IgM-rheumatoid factor (IgM-RF) were routinely determined by a nephelometric method and recorded as a qualitative (positive/negative) variable (normal values $0-15 \mathrm{U} / \mathrm{ml}$ ).

\section{Statistical analysis}

The results are expressed as mean \pm standard deviation (SD). Variables were tested for normal distribution using the Kolmogorov-Smirnov test. Comparisons between the two groups were performed using Student's t-test (parametric analysis) and the Mann-Whitney U-test (non-parametric analysis). A comparison among groups was performed using the Kruskal-Wallis test and one-way analysis of variance (ANOVA) followed by a post-hoc test adjusted with a Bonferroni correction. Pearson correlation coefficients 
were calculated. Because TWEAK levels have a skewed distribution, they were logarithmically transformed. A $P$ value of $<0.05$ was considered to be significant.

\section{RESULTS}

Demographic, clinical, and serological data of the patients with RA and the controls are given in table 1. Of the 51 patients in the study, 22 were receiving antiTNF-alpha (group 1) and 29 only DMARDs (group 2). The average treatment duration of the patients with RA was $7.3 \pm 4.9$ years. The average DAS28 scores of these patients were $3.5 \pm 1.3$. In this study, the mean age in the patients with RA and the controls was $46.7 \pm 13.6$ and $45.7 \pm 12.1$ years, respectively. The RA patients also had significantly higher mean C-reactive protein (CRP) and erythrocyte sedimentation rate (ESR) levels than the healthy controls. Thirty-seven $(72.5 \%)$ of the 51 patients with RA had anti-CCP $>25 \mathrm{U} / \mathrm{ml}$. There were no significant differences in age, gender, duration of disease, ESR, CRP, DAS28, or rheumatoid factor (RF) between the anti-TNF-alpha group 1 and the DMARD group 2 (table 2).

All the patients who were considered anti-MCV and anti-CCP were determined to have higher levels than in the controls (anti-CCP, 86.0 $\pm 73.0 \mathrm{U} / \mathrm{ml}$ and anti-MCV, 205.0 $\pm 198.3 \mathrm{U} / \mathrm{ml}$ for RA vs. anti-CCP, $7.5 \pm 7.4 \mathrm{U} / \mathrm{ml}$ and anti-MCV, 34.0 $\pm 7.6 \mathrm{U} / \mathrm{ml}$, for controls, $\mathrm{p}<0.001$ ). The serum TWEAK levels in patients with RA were not different from those of the controls $(618 \pm 259 \mathrm{pg} / \mathrm{ml}$ for RA patients, $566 \pm 137 \mathrm{pg} / \mathrm{ml}$ for controls, $\mathrm{p}=0.765$ ). The serum TWEAK levels of the controls and RA patients are displayed in a scatter plot in figure 1. The serum TWEAK levels of the anti-TNF treatment group (group 1) were lower than the controls. They were also lower than those on DMARD treatment alone, but these differences were not at a significant level. When the RA patients were divided into subgroups according to their disease activity score (inactive, moderate, very active), there was no significant difference between the serum TWEAK levels among subgroups and pairwise comparisons ( $p=0.642$ for subgroups). The patients with RA had higher serum concentrations of TNF-alpha $(24.1 \pm 11.9 \mathrm{pg} / \mathrm{ml}$ vs. $16.5 \pm 4.1 \mathrm{pg} / \mathrm{ml}$ for controls, $\mathrm{p}<0.001$ ), but the serum IL-1 levels were not different from those of the controls $(15.9 \pm 2.3 \mathrm{pg} / \mathrm{ml} \mathrm{vs}$. $15.9 \pm 0.8 \mathrm{pg} / \mathrm{ml}$ for controls, $\mathrm{p}=0.244)$. When patients were divided into the anti-TNF group and the group taking only DMARDs, there was no significant difference in the baseline serum anti-CCP and antiMCV levels between the two groups (table 2). For the RA patients on different medication, the serum TWEAK levels were similar $(536 \pm 177 \mathrm{pg} / \mathrm{ml}$ for group 1 and $679 \pm 350 \mathrm{pg} / \mathrm{ml}$ for group $2, \mathrm{p}=0.873)$.

A significant correlation was determined in patients with RA between anti-MCV and anti-CCP levels $(\mathrm{r}=0.67, \mathrm{p}<0.001)$. Also, the mTSS showed significant associations with anti-MCV and anti-CCP $(r=0.47$, $\mathrm{p}<0.001$ for anti-MCV and $\mathrm{r}=0.57, \mathrm{p}<0.001$ for anti-

Table 1. Clinical characteristics of patients with rheumatoid arthritis and controls

\begin{tabular}{|c|c|c|c|c|c|c|c|}
\hline & \multicolumn{3}{|c|}{ Patients with RA $(n=51)$} & \multicolumn{3}{|c|}{ Controls $(n=25)$} & \multirow[b]{2}{*}{$p$} \\
\hline & $\mathrm{n}$ & $\%$ & Mean \pm SD & $\mathrm{n}$ & $\%$ & Mean \pm SD & \\
\hline Age (year) & & & $46.7 \pm 13.6$ & & & $45.7 \pm 12.1$ & 0.745 \\
\hline \multicolumn{8}{|l|}{ Gender } \\
\hline Male & 12 & & & 6 & & & 0.257 \\
\hline Female & 39 & & & 19 & & & 0.257 \\
\hline Disease duration (year) & & & $7.3 \pm 4.9$ & & & - & - \\
\hline Rheumatoid factor positive & 35 & 68.6 & & - & - & & - \\
\hline Erythrocyte sedimentation rate $(\mathrm{mm} / \mathrm{h})$ & & & $31.7 \pm 19.0$ & & & $13.6 \pm 6.2$ & $<0.001$ \\
\hline C-reactive protein $(\mathrm{mg} / \mathrm{dl})$ & & & $1.3 \pm 2.0$ & & & $0.4 \pm 0.2$ & $<0.001$ \\
\hline Anti-cyclic citrullinated peptide (U/ml) & & & $86.0 \pm 73.0$ & & & $7.5 \pm 7.4$ & $<0.001$ \\
\hline Anti-modified citrullinated vimentin (U/ml) & & & $205.0 \pm 198.3$ & & & $34.0 \pm 7.6$ & $<0.001$ \\
\hline TWEAK (pg/ml) & & & $618 \pm 259$ & & & $566 \pm 137$ & 0.765 \\
\hline Tumor necrosis factor $(\mathrm{pg} / \mathrm{ml})$ & & & $24.1 \pm 11.9$ & & & $16.5 \pm 4.1$ & $<0.001$ \\
\hline Interleukin-1 (pg/ml) & & & $15.9 \pm 2.3$ & & & $15.9 \pm 0.8$ & 0.244 \\
\hline Modified total Sharp scores & & & $107.0 \pm 80.8$ & & & & \\
\hline Disease activity score 28 & & & $3.5 \pm 1.3$ & & & & \\
\hline Anti-tumor necrosis factor-alpha & 22 & 43.1 & & - & - & & - \\
\hline Disease-modifying anti-rheumatic drugs & 42 & 82.3 & & - & - & & - \\
\hline
\end{tabular}


Table 2. The comparison of groups on different medications and controls

\begin{tabular}{|c|c|c|c|c|c|c|c|c|c|c|}
\hline & \multicolumn{9}{|c|}{ Rheumatoid arthritis } & \multirow[b]{3}{*}{$p$} \\
\hline & \multicolumn{3}{|c|}{ Group $1(n=22)$} & \multicolumn{3}{|c|}{ Group $2(n=29)$} & \multicolumn{3}{|c|}{ Controls $(n=25)$} & \\
\hline & $\mathrm{n}$ & $\%$ & Mean \pm SD & $\mathrm{n}$ & $\%$ & Mean \pm SD & $\mathrm{n}$ & $\%$ & Mean \pm SD & \\
\hline Age (year) & & & $46.1 \pm 15.1$ & & & $47.1 \pm 12.5$ & & & $45.7 \pm 12.1$ & 0.917 \\
\hline \multicolumn{11}{|l|}{ Gender } \\
\hline Male & 5 & & & 7 & & & 6 & & & 0.518 \\
\hline Female & 17 & & & 22 & & & 19 & & & 0.518 \\
\hline Duration disease (year) & & & $8.2 \pm 5.0$ & & & $9.8 \pm 4.3$ & & & - & 0.226 \\
\hline C-reactive protein (mg/dl) & & & $1.2 \pm 1.4$ & & & $1.4 \pm 2.3$ & & & $0.4 \pm 0.2$ & $<0.001^{\star}$ \\
\hline $\operatorname{ESR}(\mathrm{mm} / \mathrm{h})$ & & & $30.7 \pm 20$ & & & $32.5 \pm 18.5$ & & & $13.3 \pm 6.2$ & $<0.001^{\star}$ \\
\hline Rheumatoid factor positive & $15 / 22$ & 69.2 & & $20 / 29$ & 69 & & - & - & & 0.099 \\
\hline Disease activity score 28 & & & $3.4 \pm 1.2$ & & & $3.7 \pm 1.4$ & & & - & 0.481 \\
\hline Anti-CCP (U/ml) & & & $96.7 \pm 80.1$ & & & $77.8 \pm 67.4$ & & & $7.5 \pm 7.4$ & $<0.001^{\star \star}$ \\
\hline Anti-MCV (U/ml) & & & $193.9 \pm 186.7$ & & & $213.4 \pm 209.5$ & & & $34.0 \pm 7.4$ & $<0.001^{\star *}$ \\
\hline TWEAK $(\mathrm{pg} / \mathrm{ml})$ & & & $536 \pm 177$ & & & $679 \pm 350$ & & & $566 \pm 137$ & $0.671 \dagger$ \\
\hline Interleukin $1(\mathrm{pg} / \mathrm{ml})$ & & & $15.5 \pm 0.8$ & & & $16.2 \pm 3.0$ & & & $15.9 \pm 0.8$ & 0.304 \\
\hline $\mathrm{TNF}(\mathrm{pg} / \mathrm{ml})$ & & & $30.4 \pm 15.0$ & & & $19.4 \pm 5.6$ & & & $16.5 \pm 4.1$ & $<0.001 \dagger \dagger$ \\
\hline
\end{tabular}

CCP). A negative correlation was shown between anti-CCP and DAS28 ( $r=-0.30, p=0.028$; table 3). For the serum TWEAK levels in the RA patients, there was a very weak positive correlation with DAS28 $(\mathrm{r}=0.10, \mathrm{p}=0.489)$ and a negative correlation with anti-CCP levels $(\mathrm{r}=-0.84, \mathrm{p}=0.471)$. These were not statistically significant (table 3 ). Also, there were not any statistically significant differences between the serum TWEAK levels of the patients with RA who were anti-CCP and those who were RF positive or negative $(\mathrm{p}>0.05)$.

\section{DISCUSSION}

Rheumatoid factor, which is included as part of the criterion in the ACR classification criteria for RA, is classically used as a serologic indicator of RA. ${ }^{[9]}$ It has low specificity for RA and may also be found in many diseases. Currently, available data suggests that the diagnosis of RA can benefit from testing for antibodies to citrulline-containing peptides. AntiCCP and anti-MCV are included in the peptides. They have shown an excellent diagnostic value for RA diagnosis. There have been several reports that anti-CCP might be a predictive marker for the progression of joint destruction. ${ }^{[11,12]}$ In the report of Kroot et al., ${ }^{[13]}$ anti-CCP was positive in $70 \%$ of 273 patients with early RA (less than 1 year), and patients with anti-CCP developed significantly more severe radiological damage after six years of follow-up. The Sa autoantigen can be found in the inflamed synovium of patients with RA, and anti-Sa response is directed against citrullinated vimentin. ${ }^{[14]}$ Studies have shown that anti-CCP assay appears to be superior to the anti-MCV test in the diagnostic performance of RA..$^{[2,3]}$

In their study which followed patients with early RA, Mathsson et al. ${ }^{[4]}$ reported that changes in the anti-MCV level showed a stronger correlation with

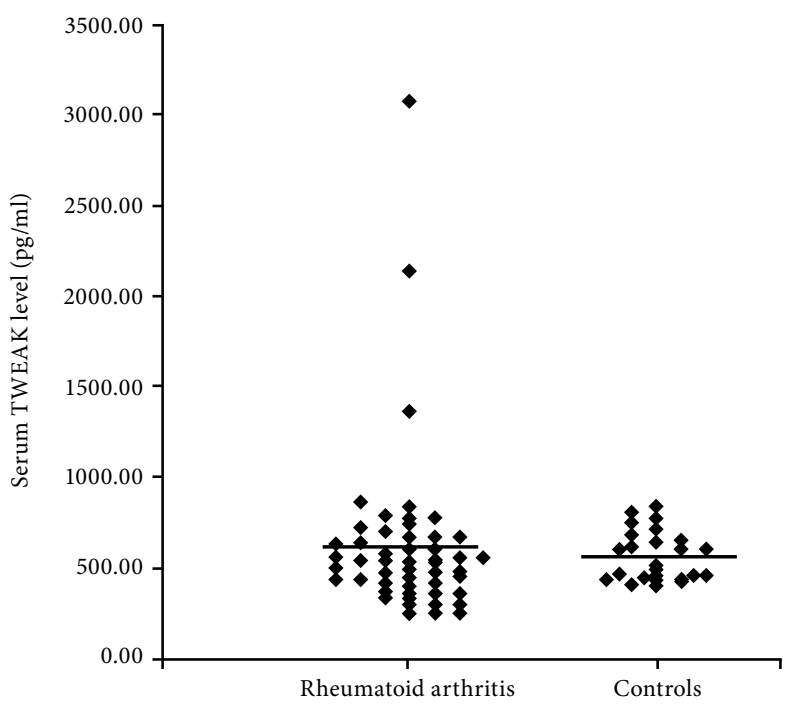

Figure 1. Serum TWEAK levels of controls and RA patients. TWEAK: TNF-related weak inducer of apoptosis. 


\begin{tabular}{|c|c|c|c|c|c|c|c|c|c|c|c|c|}
\hline & \multicolumn{2}{|c|}{ DAS28 } & \multicolumn{2}{|c|}{ Anti-MCV } & \multicolumn{2}{|c|}{ Anti-CCP } & \multicolumn{2}{|c|}{ TNF } & \multicolumn{2}{|c|}{ TWEAK log } & \multicolumn{2}{|c|}{ mTSS } \\
\hline & $\mathrm{r}$ & $\mathrm{p}$ & $\mathrm{r}$ & $\mathrm{p}$ & $\mathrm{r}$ & $\mathrm{p}$ & $\mathrm{r}$ & $\mathrm{p}$ & $\mathrm{r}$ & $\mathrm{p}$ & $\mathrm{r}$ & $\mathrm{p}$ \\
\hline DAS28 & $\mathrm{X}$ & $\mathrm{X}$ & -0.13 & 0.364 & -0.30 & 0.028 & 0.26 & 0.065 & 0.99 & 0.489 & -0.54 & $<0.001$ \\
\hline Anti-MCV & -0.13 & 0.364 & $\mathrm{X}$ & $\mathrm{X}$ & 0.67 & $<0.001$ & 0.13 & 0.259 & -0.10 & 0.391 & 0.47 & $<0.001$ \\
\hline Anti-CCP & -0.30 & 0.028 & 0.67 & $<0.001$ & $\mathrm{X}$ & $\mathrm{X}$ & 0.19 & 0.080 & -0.84 & 0.471 & 0.57 & $<0.001$ \\
\hline TNF & 0.26 & 0.065 & 0.13 & 0.259 & 0.19 & 0.080 & $\mathrm{X}$ & $\mathrm{X}$ & 0.07 & 0.515 & 0.11 & 0.437 \\
\hline TWEAK log & 0.10 & 0.489 & -0.10 & 0.391 & -0.84 & 0.471 & 0.07 & 0.515 & $\mathrm{X}$ & $\mathrm{X}$ & -0.14 & 0.313 \\
\hline mTSS & -0.54 & $<0.001$ & 0.47 & $<0.001$ & 0.57 & $<0.001$ & 0.11 & 0.437 & -0.14 & 0.313 & $\mathrm{X}$ & $\mathrm{X}$ \\
\hline
\end{tabular}

*: TWEAK levels are determined as log; Anti-CCP: Anti-cyclic citrullinated peptide; Anti-MCV: Anti-modified citrullinated vimentin; TWEAK: TNF-related weak inducer of apoptosis; DAS28: Disease activity score 28; mTSS: Modified total Sharp scores.

changes in clinical parameters than it did with changes in the anti-CCP level. The presence of anti-MCV was predictive of subsequent high disease activity and continued radiographic progression in early RA. Also, anti-MCV seems to perform better than antiCCP in detecting poor radiographic prognosis. In that study, Mathsson et al. ${ }^{[4]}$ has reported that the analysis of anti-MCV yields greater sensitivity and unchanged specificity compared with the analysis of anti-CCP. Similarly, Boire et al. ${ }^{[5]}$ reported that anti $\mathrm{Sa} /$ vimentin antibodies had better prognostic markers of radiographic destruction than did anti$\mathrm{CCP}$ and RF.

It is now recognized that in established RA patients the chronic inflammation in the synovium is likely to be self-perpetuated by synovial macrophages and fibroblasts through cytokine mediators, including TNF, IL-1, IL-6, and others. The macrophage-derived TNF is considered a more upstream player due to its ability to induce the production of other cytokines in synovial fibroblasts, thus underlying the effectiveness of anti-TNF-alpha in studies. ${ }^{[15]}$ TWEAK is a member of the TNF superfamily of structurally-related cytokines and is a secreted protein with cytotoxic and proinflammatory activities. TWEAK was also shown to act as a growth factor by inducing the proliferation of endothelial cells. ${ }^{[16]}$ However, little is known about the effect of anti-TNF-alpha on TWEAK expression. Park et al. ${ }^{[8]}$ reported that serum levels of TWEAK were significantly elevated in patients with RA, and indicated a short-lived response to anti-TNF-alpha. However, in anti-TNF-alpha non-responder patients, the serum TWEAK levels were reported to remain unchanged. $^{[8]}$ In a recent study, TWEAK and its fibronectin (FN) receptor were found to be expressed in the inflamed synovium of RA and psoriatic arthritis patients. Of particular interest was the fact that
TWEAK and FN expression were unchanged after four weeks of anti-TNF-alpha treatment. ${ }^{[17]}$

In our study, when the patient groups and controls were compared for anti-MCV and anti-CCP, there was a statistically significant difference. The anti-MCV levels showed a significant correlation between anti-CCP and the mTSS, but there was no correlation with the serum TWEAK levels. Also, there was a significant association between anti-CCP and the mTSS. Our findings are consistent with those of Mathsson et al. ${ }^{[4]}$ Contrary to relevant literature, the serum TWEAK levels of the RA patients were not significantly different from those of the controls. In Turkey, anti-TNF treatments are applied to those patients resistant to combined DMARDs therapy and with high disease activity (DAS28 score $>5.1$ ). About half of the study population was on anti-TNF-alpha therapy. These therapies may cause a reduction of serum TWEAK levels. This may also explain our findings which are contrary to the current literature that shows a slightly higher, but non-significant difference of serum TWEAK levels in patients with RA.

Although there are similar studies in the literature, one of the novel aspects of our study is the high number of patients on anti-TNF-alpha treatment in our series. Our patients had been receiving this treatment for at least five months. One limitation of this study is that we had no pretreatment data prior to the series.

In this study, we detected similar serum TWEAK levels in the patients with RA and the controls, and the levels of anti-MCV and anti-CCP were determined to be higher in the RA patients than in the controls. Also, these citrullinated peptides were correlated with mTSS. However, future comprehensive studies are needed for more conclusive evaluation of serum TWEAK, anti$\mathrm{CCP}$, and anti-MCV in RA patients. 


\section{Declaration of conflicting interests}

The authors declared no conflicts of interest with respect to the authorship and/or publication of this article.

\section{Funding}

The authors received no financial support for the research and/or authorship of this article.

\section{REFERENCES}

1. Mimori T. Clinical significance of anti-CCP antibodies in rheumatoid arthritis. Intern Med 2005;44:1122-6.

2. Sghiri R, Bouajina E, Bargaoui D, Harzallah L, Fredj HB, Sammoud S, et al. Value of anti-mutated citrullinated vimentin antibodies in diagnosing rheumatoid arthritis. Rheumatol Int 2008;29:59-62.

3. Dejaco C, Klotz W, Larcher H, Duftner C, Schirmer M, Herold M. Diagnostic value of antibodies against a modified citrullinated vimentin in rheumatoid arthritis. Arthritis Res Ther 2006;8:R119.

4. Mathsson L, Mullazehi M, Wick MC, Sjöberg O, van Vollenhoven R, Klareskog L, et al. Antibodies against citrullinated vimentin in rheumatoid arthritis: higher sensitivity and extended prognostic value concerning future radiographic progression as compared with antibodies against cyclic citrullinated peptides. Arthritis Rheum 2008;58:36-45.

5. Boire G, Cossette P, de Brum-Fernandes AJ, Liang P, Niyonsenga T, Zhou ZJ, et al. Anti-Sa antibodies and antibodies against cyclic citrullinated peptide are not equivalent as predictors of severe outcomes in patients with recent-onset polyarthritis. Arthritis Res Ther 2005;7:R592-603.

6. Wiley SR, Winkles JA. TWEAK, a member of the TNF superfamily, is a multifunctional cytokine that binds the TweakR/Fn14 receptor. Cytokine Growth Factor Rev 2003;14:241-9.

7. Toussirot E, Wendling D. The use of TNF-alpha blocking agents in rheumatoid arthritis: an overview. Expert Opin Pharmacother 2004;5:581-94.
8. Park MC, Chung SJ, Park YB, Lee SK. Relationship of serum TWEAK level to cytokine level, disease activity, and response to anti-TNF treatment in patients with rheumatoid arthritis. Scand J Rheumatol 2008;37:173-8.

9. Arnett FC, Edworthy SM, Bloch DA, McShane DJ, Fries JF, Cooper NS, et al. The American Rheumatism Association 1987 revised criteria for the classification of rheumatoid arthritis. Arthritis Rheum 1988;31:315-24.

10. van der Heijde D. How to read radiographs according to the Sharp/van der Heijde method. J Rheumatol 2000;27:261-3.

11. Forslind K, Ahlmén M, Eberhardt K, Hafström I, Svensson B; BARFOT Study Group. Prediction of radiological outcome in early rheumatoid arthritis in clinical practice: role of antibodies to citrullinated peptides (anti-CCP). Ann Rheum Dis 2004;63:1090-5.

12. Schellekens GA, Visser H, de Jong BA, van den Hoogen FH, Hazes JM, Breedveld FC, et al. The diagnostic properties of rheumatoid arthritis antibodies recognizing a cyclic citrullinated peptide. Arthritis Rheum 2000;43:155-63.

13. Kroot EJ, de Jong BA, van Leeuwen MA, Swinkels $H$, van den Hoogen FH, van't Hof M, et al. The prognostic value of anti-cyclic citrullinated peptide antibody in patients with recent-onset rheumatoid arthritis. Arthritis Rheum 2000;43:1831-5.

14. Vossenaar ER, Després N, Lapointe E, van der Heijden A, Lora M, Senshu T, et al. Rheumatoid arthritis specific anti-Sa antibodies target citrullinated vimentin. Arthritis Res Ther 2004;6:R142-50.

15. Perper SJ, Browning B, Burkly LC, Weng S, Gao C, Giza K, et al. TWEAK is a novel arthritogenic mediator. J Immunol 2006;177:2610-20.

16. Chicheportiche Y, Chicheportiche R, Sizing I, Thompson J, Benjamin CB, Ambrose C, et al. Proinflammatory activity of TWEAK on human dermal fibroblasts and synoviocytes: blocking and enhancing effects of anti-TWEAK monoclonal antibodies. Arthritis Res 2002;4:126-33.

17. van Kuijk AW, Wijbrandts CA, Vinkenoog M, Zheng TS, Reedquist KA, Tak PP. TWEAK and its receptor Fn14 in the synovium of patients with rheumatoid arthritis compared to psoriatic arthritis and its response to tumour necrosis factor blockade. Ann Rheum Dis 2010;69:301-4. 